\title{
A Case Study
}

\section{Impact assessment: A case study of Bengal gram (Deshi) pre-harvest price forecast released by NAIP, AMIC}

\section{V.K. PATIL AND A.S. TINGRE}

See end of the paper for authors' affiliations

Correspondence to :

\section{V.K. PATIL}

Department of

Agricultural Economics and Statistics, Vivekanand College of Agri Business Management (P.D.K.V.), Hiwara (M.S.) INDIA Email: mr.esctacy2008@ gmail. com

Paper History : Received : 04.08.2014; Accepted : 19.02.2015 2012.
ABSTRACT : The present study was undertaken to analyze and capture the impact of price forecast of Bengal gram (Deshi) released by the NAIP, AMIC during February, 2012. Monthly time series data on average prices of Bengal gram (Deshi) for the period from 2000 to 2012 were collected from APMC, Akola. Various univariate time series models were tried to analyze the data and forecasted prices were calculated. Finally a market advisory was prepared and released through different mass media like news papers, voice SMS and university website. To study the impact assessment of price forecast out of 52 farmers who attended the training programme conducted by AMIC, Dr. Panjabrao Deshmukh Krishi Vidyapeeth, Akola at village Talegaon, taluka Telhara, district Akola about 39 farmers who adopted the advice were selected and interviewed. It was found that winters multiplicative model was the best fit model with lowest MAPE. The price forecast for the months from February to June, 2012 was Rs. 3000-3300 per quintal and higher prices could be received during April to May. Based on the above price levels, farmers were recommended to store and sell from April to May. On an average 1.46 ha area was operated under Bengal gram (Deshi) crop. Average price realized by the farmers during March, 2012 was Rs. 2800 per quintal, whereas, those who retained Bengal gram (Deshi) according to advice given by AMIC, Dr. Panjabrao Deshmukh Krishi Vidyapeeth, Akola realized Rs. 3800 per quintal during May to June, 2012. Thus, an incremental income realized to the extent of Rs. 22374 per hectare by the farmers who sold their produce during May-June,

KEY WORDS : Impact assessment, Bengal gram, Pre-harvest price

HOW TO CITE THIS PAPER : Patil, V.K. and Tingre, A.S. (2015). Impact assessment: A case study of Bengal gram (Deshi) pre-harvest price forecast released by NAIP, AMIC. Internat. Res. J. Agric. Eco. \& Stat., 6 (1) : 197-200. 